\title{
Muscle and Subcutaneous Fatty Acid Composition and the Evaluation of Ageing Time on Meat Quality Parameters of Hispano-Bretón Horse Breed
}

\author{
Lorea R. Beldarrain ${ }^{1}$, Lara Morán ${ }^{1}{ }^{\circledR}$, Miguel Ángel Sentandreu ${ }^{2}$, Kizkitza Insausti ${ }^{3}{ }^{\mathbb{D}}$, Luis Javier R. Barron ${ }^{1} \mathbb{C}$ \\ and Noelia Aldai ${ }^{1, *(\mathbb{B})}$ \\ 1 Lactiker Research Group, Department of Pharmacy \& Food Sciences, University of the Basque \\ Country (UPV/EHU), 01006 Vitoria-Gasteiz, Spain; lorea.rivera@ehu.eus (L.R.B.); \\ lara.moran@ehu.eus (L.M.); luisjavier.rbarron@ehu.eus (L.J.R.B.) \\ 2 Instituto de Agroquímica y Tecnología de Alimentos (CSIC), 46980 Paterna, Spain; ciesen@iata.csic.es \\ 3 IS-FOOD, Research Institute for Innovation \& Sustainable Development in Food Chain, Public \\ University of Navarre (UPNA), 31006 Pamplona, Spain; kizkitza.insausti@unavarra.es \\ * Correspondence: noelia.aldai@ehu.eus
}

\section{check for} updates

Citation: Beldarrain, L.R.; Morán, L.; Sentandreu, M.Á.; Insausti, K.; R. Barron, L.J.; Aldai, N. Muscle and Subcutaneous Fatty Acid

Composition and the Evaluation of Ageing Time on Meat Quality Parameters of Hispano-Bretón Horse Breed. Animals 2021, 11, 1421 https://doi.org/10.3390/ani11051421

Academic Editor: Aristide Maggiolino

Received: 6 March 2021

Accepted: 12 May 2021

Published: 15 May 2021

Publisher's Note: MDPI stays neutral with regard to jurisdictional claims in published maps and institutional affiliations.

Copyright: (c) 2021 by the authors. Licensee MDPI, Basel, Switzerland. This article is an open access article distributed under the terms and conditions of the Creative Commons Attribution (CC BY) license (https:// creativecommons.org/licenses/by/ $4.0 /)$.
Simple Summary: Horse meat; even though is still not popular in most countries; its consumption is slowly increasing and has the potential to become an alternative future red meat. However; research is still insufficient and a deeper understanding of its nutritional and physicochemical characteristics would be beneficial for the horse meat industry. The capacity of horses to efficiently uptake polyunsaturated fatty acids into their tissues has been reported; but detailed knowledge about horse meat fatty acid composition is limited. The present work provides a comprehensive fatty acid composition analysis of subcutaneous and muscle tissues from semiextensively reared HispanoBreton horses; results indicated that finishing on a high-grain diet limited muscle n-3 accumulation. In addition; the evolution of physicochemical quality parameters such as $\mathrm{pH}$, instrumental color, texture and cook loss were thoroughly studied during vacuum ageing $(0,7,14$ and 21 days), and the conclusion was that an ageing period between 7 and 14 days would be recommended for an optimum horse meat quality. The reasons for this recommendation were that tenderness increased during the first two weeks and then stayed stable and that visual properties deteriorated after 14 days. Overall; these results will help to standardize post mortem practices to obtain a homogeneous final horse meat quality.

Abstract: A full-randomized block design was used for the study of the FA composition and meat quality parameters, considering ageing time as a split-plot factor. Chemical and fatty acid composition of steaks (longissimus thoracis and lumborum muscle) from 15 month old semiextensively reared Hispano-Bretón horses were characterized (day 0), and the effect of vacuum ageing $(0,7,14$ and 21 days) on several meat quality parameters ( $\mathrm{pH}$, instrumental color and texture and cook loss) was determined. The average fat content of horse loin was $3.31 \%$, and the $n-3$ polyunsaturated fatty acid content, although higher than in ruminant meats, suggested that the finishing on a highgrain diet limited muscle n-3 accumulation. Results revealed that ageing affected all meat quality measurements; color started to turn brownish at 14 days of ageing, with a decrease in redness but not in yellowness. Tenderness improved during the first two weeks, and the Warner-Bratzler shear force scores showed that meat aged for 7 days could be considered as 'intermediate tender'. Under the present study conditions, an ageing period between 7 and 14 days is recommended for an optimum horse meat quality.

Keywords: ageing; color; equine; foal; intramuscular fat; texture 


\section{Introduction}

Horse meat, due to religious and/or cultural reasons, is still not popular [1,2]. Nevertheless, its consumption is slowly increasing in several countries due to its recognized nutritional value, mainly related to grazing systems [3]. Even though the effects of horse meat consumption on human health have not been widely studied [4], several investigations have addressed the interest of its nutritional properties with special attention on its lipid composition, which is a direct consequence of the equine digestive physiology [5-8]. Horses are non-ruminant herbivores and hindgut fermenters that efficiently digest and absorb the major part of dietary lipids in the foregut, before reaching microbial metabolism in the hindgut $[9,10]$. Thereupon, lipid composition of horse muscle tissue is generally characterized by high levels of polyunsaturated fatty acids (PUFAs) [11] and low levels of branched-chain fatty acids (BCFAs), trans-fatty acids and conjugated linolenic acids (CLA); that are all associated with rumen metabolism and are, therefore, more abundant in ruminant derived products [12-14]. Recent investigations have opened an interesting research field describing plasmalogenic lipids in horse tissues $[5,15]$ that deserve further research due to their implications in human health $[16,17]$. Regarding horse meat quality, a number of studies have been performed in several breeds slaughtered at different ages [18-22] but there is still no general agreement concerning the post mortem ageing of horse meat and its effect on the final meat quality [23].

In this context, meat ageing has been commonly applied in the meat industry for decades [24]. In particular, vacuum packaging of subprimals or cuts for a certain period of cooling storage, namely wet ageing, is the most extended type of ageing [25]. This process is widely known to have a pivotal role in the improvement of meat palatability, especially tenderness [26], and variation in color [27,28], while avoiding contamination and weight loss.

The role of ageing and biochemical mechanisms involved in the improvement of meat tenderness have been widely studied [29,30], and it is well known that the level of tenderization will majorly depend on duration and temperature of the ageing process, together with other factors such as muscle type, breed and animal species [31]. Regarding color, when meat is vacuum packaged, the oxygen depleted atmosphere causes meat surface turn purple color (deoxymyoglobin) and when the package is opened and exposed to air (oxygenated), purple turns back to red color (oxymyoglobin). As the ageing process progresses, oxygen consumption of respiratory enzymes within mitochondria decreases, resulting in more oxygen available to bind myoglobin and form a thicker layer of oxymyoglobin under the surface; this fact translates into a redder meat after oxygenation [26]. However, in extended ageing, the residual oxygen can oxidize oxymyoglobin and deoxymyoglobin, leading to the formation of a brownish layer (metmyoglobin). In essence, as post mortem time increases, the reduction ability of muscle decreases and, consequently, the formed metmyoglobin cannot be converted back, giving rise to meat discoloration and brownish color $[27,32]$. It is known that myoglobin content and reduction activity are muscle and species specific [33].

The implications of ageing process in meat quality have been extensively studied in beef [34], in pork [35] and in sheep meat [36], but only few studies have been performed in horse meat in which, again, differences in animal age and breed are considerable [23,37-41].

Considering the variability of the results obtained and the numerous sources of variation, specific conditions to maximize ageing positive impacts in horse meat are far from being understood and, therefore, further studies are needed. In this regard, the aim of the present work is to study the effect of ageing time (0, 7, 14 and 21 days) in meat quality parameters. This knowledge is necessary to contribute to the recommendation of a certain ageing period, based on quality parameters, for the horse meat industry. Moreover, a thorough characterization of fatty acid (FA) composition of two horse fat tissues, muscle and subcutaneous (SC), has been reported. 


\section{Materials and Methods}

\subsection{Animal Handling}

Ten Hispano-Bretón horses (five females and five males) were reared in a commercial farm under grazing conditions while suckling their mothers from birth (May-June 2017) until weaning (6-8 months of age). Then, they continued grazing until 11-13 months of age, when they were moved to a commercial feedlot and finished for 100-120 days on a high-grain diet and straw ad libitum. Concentrate was composed by barley, soybean hulls, molasses, palm oil and salts (13.3\% protein, $2.70 \%$ fat and $7.60 \%$ fiber).

Horses were slaughtered in a commercial abattoir, following the specifications in the European legislation [42], at 15-17 months of age. More details about the experimental design have been previously described [43].

The average carcass weight was of $246 \pm 14.0 \mathrm{~kg}(250 \pm 15.0 \mathrm{~kg}$ for females and $242 \pm 12.5 \mathrm{~kg}$ for males). All carcasses were classified as U (conformation) and 2 (fat cover) according to the community scale for the classification of carcasses of adult bovine animals [44] as there is no specific classification system for horses at the EU level.

\subsection{Experimental Design and Sampling}

A full-randomized block design was used considering slaughter day as a blocking factor. Fat tissue was the main factor in the study of the variability of the FA composition of non-aged horse meat samples, and ageing time when assessing the variability of meat quality parameters. In both studies, the loin was the experimental unit. Animal sex, carcass side and carcass weight were distorting variation sources controlled by the experimental design in order to minimize the residual variation. For assessing the effect of ageing time on meat quality parameters a split plot design was used where ageing time levels were randomly allocated to different individual steaks obtained from the loin of each carcass. In this case, the experimental unit (loin) was considered as a plot and the steaks were the subplots (sampling units) in which ageing time effect was assessed.

Two horses (female and male) were slaughtered per week during five consecutive weeks. After $48 \mathrm{~h}$ post mortem at $4{ }^{\circ} \mathrm{C}$ (day 0), both right and left rib sections were removed from carcasses and transported to the laboratory under refrigerated conditions (total number of loins $=20$ ). The loin, longissimus thoracis and lumborum (LTL) muscle, was excised, trimmed of visible adipose and connective tissues and cut into 10 consecutive steaks $(1.5 \mathrm{~cm}$ thick) from the thoracic side. The first two steaks were trimmed, divided in three similar portions, vacuum packed and frozen $\left(-80^{\circ} \mathrm{C}\right)$ for chemical and FA composition and myoglobin content determinations, respectively. A portion of SC fat (20-30 mg) taken from the thoracic region of the loin was also vacuum packed and frozen at $-80{ }^{\circ} \mathrm{C}$ for FA profile determination. The following four steaks were vacuum packed and randomly assigned to an ageing time: $0,7,14$ or $21 \mathrm{~d}$ for instrumental color, cooked loss and instrumental texture determinations. The same procedure was used for the last four steaks used for $\mathrm{pH}$ measurements. Ageing was performed in a walk-in cooler $\left(4 \pm 1^{\circ} \mathrm{C}\right)$ and without illumination. After instrumental color was determined (unpacked and bloomed samples), the steaks were vacuum packed again and frozen at $-80^{\circ} \mathrm{C}$ for further cook loss and instrumental texture determinations.

\subsection{Chemical and Fatty Acid Composition}

Chemical and FA compositions were determined only in non-aged steaks as not relevant compositional changes were expected within $21 \mathrm{~d}$ of ageing. Standard procedures were used for dry matter [45], crude protein [46], ether extract [47] and ash [48] determinations.

For SC fat analysis, $50 \pm 1 \mathrm{mg}$ of middle layer adipose tissue were freeze-dried and directly methylated with sodium methoxide (Methanolic-Base, $0.5 \mathrm{~N}$; Supelco Inc., Bellefonte, PA, USA) using $1 \mathrm{~mL}$ of internal standard (4 mg/mL of methyl ester (ME) 23:0; Nu-Check Prep. Inc., Elysian, MN, USA). For muscle tissue, total lipids were extracted from $1 \mathrm{~g}$ of freeze-dried horse meat with chloroform-methanol (2:1, v/v) [49]. Lipid aliquots of $10 \mathrm{mg}$ were methylated using anhydrous methanol containing $2 \% \mathrm{H}_{2} \mathrm{SO}_{4}$ [16]. Prior to 
methylation, $1 \mathrm{~mL}$ of internal standard $(1 \mathrm{mg} / \mathrm{mL}$ of 23:0 ME) was added. For both tissues, muscle and SC fat tissues, FAMEs were analyzed using a 7890A gas chromatograph (GC) with flame ionization detector (Agilent Technologies, Madrid, Spain) coupled to a 7693 automatic injector (Agilent Technologies). Separation was carried out using a SP-2560 column (100 m, $0.25 \mathrm{~mm}$ i.d. and $0.20 \mu \mathrm{m}$ film thickness; Supelco. Bellefonte, PA, USA) and following the conditions described by Kramer et al. [50]. Peak identification was performed using commercial reference standards (\#463 and \#603 mixtures, individual 21:0, 23:0 FAMEs and a CLA mixture \#UC-59 M composed by $9 c, 11 t-/ 8 t, 10 c-/ 11 c, 13 t-/ 10 t, 12 c-$ $/ 8 c, 10 c-/ 9 c, 11 c-/ 10 c, 12 c-/ 11 c, 13 c-/ 11 t, 13 t-/ 10 t, 12 t-/ 9 t, 11 t-/ 8 t, 10 t-18: 2$ obtained from NuChek Prep Inc., Elysian, MN, USA; BCFA containing bacterial mixture purchased from Matreya, Pleasant Gap, PA, USA), confirmed using FAME fractions obtained from silver-ion solid phase extraction glass cartridges [51,52], and following retention times and elution orders reported in the literature $[5,50,53]$. Chromatographic areas were corrected according to theoretical response factors [54] and internal standard was used to calculate quantitative data (mg per $\mathrm{g}$ of SC fat tissue and $\mathrm{mg}$ per $100 \mathrm{~g}$ fresh meat). Then, FAME contents were expressed as percentages (\%). In general, FAMEs representing below $0.05 \%$ were excluded to reduce the size of tables, except for minor FAMEs of particular nutritional interest.

\section{4. $p H$ Measurements}

Triplicate $\mathrm{pH}$ measurements were taken in each steak at each ageing time $(0,7,14$ and $21 \mathrm{~d}$ ) using a portable pH meter (HI99163, Hanna Instruments, Smithfield, RI, USA) equipped with a penetrating glass electrode (FC232D, Hanna Instruments, USA).

\subsection{Myoglobin Content Determinations}

Total myoglobin content was measured in non-aged steaks as not relevant changes were expected over ageing time. The method by Faustman and Philips [55], with minor modifications was followed. Previously thawed $\left(4^{\circ} \mathrm{C}\right.$, overnight) and minced (domestic grinder) $5 \mathrm{~g}$ of meat were homogenized in iced cold sodium phosphate buffer and set aside for $1 \mathrm{~h}\left(4^{\circ} \mathrm{C}\right.$, darkness). Samples were then centrifuged $(32,000 \times \mathrm{g})$ for $45 \mathrm{~min}$ and filtered through a Whatman filter paper ( ${ }^{\circ} 1$, Whatman PLC, UK). Absorbance was read at $525 \mathrm{~nm}$ in a UV 1280 spectrophotometer (Shimadzu Corporation, Japan) and the total myoglobin concentration was estimated applying the extinction coefficient of $7.6 \mathrm{mM}^{-1} \mathrm{~cm}^{-1}$ as proposed by Bowen [56].

\subsection{Instrumental Color Measurements}

For instrumental color measurements, color in non-aged steaks was measured after they were cut, covered with an oxygen-permeable polyvinylchloride film (oxygen permeability of $\left.580 \mathrm{~mL} / \mathrm{m}^{2} / \mathrm{h}\right)$ and exposed to air for $1 \mathrm{~h}\left(4^{\circ} \mathrm{C}\right)$. The rest of the color measurements were taken when the corresponding ageing period was reached. As for $0 \mathrm{~d}$, steaks were unpacked, covered with film and exposed to air for $1 \mathrm{~h}\left(4^{\circ} \mathrm{C}\right)$. A Minolta CR-200 colorimeter (Konica Minolta, Japan) with a D65 illuminant and a $10^{\circ}$ visual angle was used to measure $L^{*}$ (lightness), $a^{*}$ (redness) and $b^{*}$ (yellowness) values according to CIELAB color space [57]. Five spectral readings per sample were taken in different parts of the steaks. From these measurements, two additional color parameters were calculated: hue angle $\left(h^{*}\right)$, which defines color $=$ arctangent $\left(b^{*} / a^{*}\right)$ and chroma or saturation index $\left(C^{*}\right)=\left(a^{* 2}+b^{* 2}\right)^{1 / 2}(\mathrm{AMSA}, 2012)$.

\subsection{Cook Loss Determinations}

Steaks were thawed overnight $\left(4^{\circ} \mathrm{C}\right)$ and after $1 \mathrm{~h}$ at room temperature, they were weighted, individually introduced in open plastic bags and cooked in a water bath at $80^{\circ} \mathrm{C}$ (SV Thermo, Orved, Italy) until they reached an internal temperature of $71 \pm 0.1^{\circ} \mathrm{C}$, monitored by temperature probes (TFA-301040, TFA, Germany). Cooking was performed in batches of 8 steaks, which were randomly chosen ( 2 sets of 4 ageing times). Then, steaks were removed from the water bath and cooled at room temperature for $1 \mathrm{~h}$. Excess moisture 
was eliminated and samples were reweighted. Cook loss was determined calculating the weight difference between raw and cooked steaks [58].

\subsection{Instrumental Texture Measurements}

For instrumental texture measurements, 8 cuboids of approximately $1 \times 1.5 \times 1 \mathrm{~cm}^{3}$ were cut from each cooked steak and parallel to the muscle fibers. Maximum WarnerBratzler shear force (WBSF) of each cuboid was measured using a TA-XT2i texture analyzer (Stable Micro Systems, UK) connected to an IBM-compatible Foxen computer, with an AutenticAMD-K6 ${ }^{\mathrm{TM}}$ 3D microprocessor. The 'Texture Expert' software, version 1.22 for Windows (Stable Micro Systems, Surrey, UK) was used. The texture analyzer was equipped with a WBSF device (cutting blade at a constant speed of $1.70 \mathrm{~mm} / \mathrm{s}$ and a load cell of $300 \mathrm{~N})$.

\subsection{Statistical Analysis}

Analyses were conducted using IBM-SPSS Statistics Software (Version 25.0, IBM Corporation, Chicago, IL, USA). Normality and homoscedasticity of the variables were checked and $\mathrm{pH}$ values were $\log$ transformed.

The general linear model (GLM) of ANOVA was used to determine, separately, the significant differences in the FA composition between fat tissues (muscle and subcutaneous fat) of non-aged horse meat samples, and in the instrumental color $\left(L^{*}, a^{*}, b^{*}, C^{*}, h^{*}\right)$, $\mathrm{pH}$, cook loss and WBSF measurements of horse meat samples among ageing times $(0$, 7, 14 and $21 \mathrm{~d}$ ). The GLMs included the corresponding main factor and the controlled distorting variation factors (animal sex and carcass side) as fixed effects, and carcass weight as a covariate. Slaughter day was also included as a random effect because this blocking factor was a simultaneous distorting factor of uncontrolled variation coming from at least individual animal, feeding, transport or slaughter conditions. Moreover, GLMs included binary interactions between all factors.

Eta square $\left(\eta^{2}\right)$ was used for effect size estimation and Fisher's least significance difference test of estimated marginal means was used for pairwise comparisons among ageing time levels. Three significant figures were used to express data and significance was declared at $p \leq 0.05$.

\section{Results and Discussion}

\subsection{Chemical and Fatty Acid Composition}

Chemical composition (\%) and muscle FA composition in absolute basis (mg/100 g of raw meat) are reported in Table 1. Mean moisture (75.3\%) was comparable to values described in the literature for $15-16$ month old horse loins $[7,59,60]$. As expected, mean protein content $(20.4 \%)$ was also in the range of values reported in the literature for different horse breeds, ages and production systems $(19-22 \% ;[7,19,21,23,59-63])$. The muscle fat content obtained in the present study (3.31\%) was comparable to other studies where horses were extensively reared, finished on concentrates and slaughtered at similar ages $[7,19,60]$. Ash content in horse meat has been reported to vary due to the age of animals [64] while the mineral content of feedstuffs may also have an influence [64]. The results obtained in the present study $(1.03 \%)$ were in line with meat from horses slaughtered at similar age $[7,19,59]$.

In terms of FA composition, in absolute basis (Table 1), wide ranges were observed while these differences were substantially reduced in percentage basis (Tables 2-4). Variable lipid content in horse meat has been previously reported, depending primarily on animalrelated (i.e., breed, age, feeding) but also methodology-related (i.e., fat extraction procedure) factors [3]. 
Table 1. Chemical (\%) and fatty acid (absolute basis: $\mathrm{mg} / 100 \mathrm{~g}$ of meat) composition of horse longissimus thoracis and lumborum muscle $(n=20)$.

\begin{tabular}{ccccc}
\hline & Mean & Min & Max & SEM \\
\hline Chemical composition & & & & \\
Moisture & 75.3 & 72.9 & 78.1 & 0.3 \\
Crude protein & 20.4 & 19.1 & 22.3 & 0.2 \\
Fat (ether extract) & 3.31 & 1.87 & 5.13 & 0.19 \\
Ash & 1.03 & 0.750 & 1.17 & 0.02 \\
Fatty acid composition & & & \\
Total FAME & 2427 & 893 & 4238 & 199 \\
SFA & 956 & 333 & 1743 & 85 \\
BCFA & 4.98 & 2.32 & 7.97 & 0.35 \\
MUFA & 1054 & 380 & 1877 & 93 \\
cis-MUFA & 1051 & 378 & 1872 & 92 \\
trans-MUFA & 3.32 & 1.07 & 5.42 & 0.29 \\
CLA (18:2) & 2.75 & 1.42 & 4.36 & 0.21 \\
NC-dienes (18:2) & 1.40 & 0.814 & 2.91 & 0.11 \\
Trienes (18:3) & 0.522 & 0.105 & 1.14 & 0.05 \\
PUFA & 345 & 147 & 546 & 22 \\
n-6 & 266 & 113 & 390 & 15 \\
18:2n-6 & 231 & 96 & 350 & 14 \\
n-3 & 78 & 25 & 177 & 8 \\
18:3n-3 & 56.1 & 15.6 & 154 & 8 \\
DMA & 60.3 & 26.6 & 84.7 & 3.3
\end{tabular}

Min, minimum value; Max, maximum value; SEM, standard error of the mean. FAME, fatty acid (FA) methyl esters; SFA, saturated FA; BCFA, branched-chain FA; MUFA, monounsaturated FA; CLA, conjugated linoleic acids; NC, non-conjugated; PUFA, polyunsaturated FA; DMA, dimethylacetals (sum of DMA, AME (alk-1-enyl methyl ethers) and ALD (fatty aldehydes).

Table 2. Effect of fat tissue (muscle and subcutaneous fat) on the saturated and branched-chain fatty acid composition of horse meat in percentage basis $(\%)(n=20)$.

\begin{tabular}{|c|c|c|c|c|c|c|c|}
\hline & \multicolumn{4}{|c|}{ Muscle } & \multicolumn{2}{|c|}{ Subcutaneous } & \multirow{2}{*}{$p$-Value } \\
\hline & Mean & Min & Max & SEM & Mean & SEM & \\
\hline SFA & 38.9 & 36.8 & 43.8 & 0.3 & 39.5 & 0.5 & 0.383 \\
\hline 12:0 & 0.206 & 0.151 & 0.256 & 0.006 & 0.224 & 0.008 & 0.079 \\
\hline 14:0 & 3.65 & 3.00 & 4.58 & 0.09 & 4.33 & 0.09 & $<0.001$ \\
\hline $15: 0$ & 0.274 & 0.186 & 0.429 & 0.015 & 0.410 & 0.017 & $<0.001$ \\
\hline $16: 0$ & 29.3 & 26.8 & 31.3 & 0.3 & 29.9 & 0.4 & 0.256 \\
\hline $17: 0$ & 0.357 & 0.238 & 0.489 & 0.015 & 0.505 & 0.020 & $<0.001$ \\
\hline 18:0 & 4.79 & 4.38 & 5.50 & 0.09 & 3.85 & 0.14 & $<0.001$ \\
\hline $20: 0$ & 0.0590 & 0.0450 & 0.0700 & 0.0020 & 0.0496 & 0.0017 & $<0.001$ \\
\hline $22: 0$ & 0.0665 & 0.0370 & 0.106 & 0.0039 & 0.0138 & 0.0018 & $<0.001$ \\
\hline BCFA & 0.211 & 0.176 & 0.260 & 0.006 & 0.285 & 0.012 & $<0.001$ \\
\hline$i-16: 0$ & 0.0890 & 0.068 & 0.107 & 0.0023 & 0.0844 & 0.0037 & 0.297 \\
\hline
\end{tabular}

Min, minimum value; Max, maximum value; SEM, standard error of the mean. SFA, saturated fatty acids (FA); BCFA, branched-chain FA. 
Table 3. Effect of fat tissue (muscle and subcutaneous fat) on the monounsaturated fatty acid composition of horse meat in percentage basis $(\%)(n=20)$.

\begin{tabular}{cccccccc}
\hline & \multicolumn{4}{c}{ Muscle } & \multicolumn{4}{c}{ Subcutaneous } & \multirow{2}{*}{$\boldsymbol{p}$-Value } \\
\cline { 2 - 7 } & Mean & Min & Max & SEM & Mean & SEM & \\
\hline MUFA & 42.9 & 37.6 & 47.7 & 0.6 & 44.3 & 0.4 & 0.074 \\
cis-MUFA & 42.8 & 37.4 & 47.5 & 0.6 & 44.2 & 0.4 & 0.076 \\
$9 c-14: 1$ & 0.412 & 0.297 & 0.511 & 0.013 & 0.389 & 0.016 & 0.295 \\
$7 c-16: 1$ & 0.182 & 0.138 & 0.272 & 0.008 & 0.328 & 0.014 & $<0.001$ \\
$9 c-16: 1$ & 8.09 & 5.602 & 9.693 & 0.27 & 7.58 & 0.23 & 0.174 \\
$9 c-18: 1$ & 31.4 & 27.4 & 34.1 & 0.4 & 32.7 & 0.4 & 0.025 \\
$11 c-18: 1$ & 1.93 & 1.57 & 2.22 & 0.04 & 1.51 & 0.03 & $<0.001$ \\
$13 c-18: 1$ & 0.0965 & 0.0740 & 0.119 & 0.0027 & 0.0531 & 0.0017 & $<0.001$ \\
$11 c-19: 1$ & 0.0675 & 0.0491 & 0.0880 & 0.0027 & 0.0738 & 0.0042 & 0.201 \\
$11 c-20: 1$ & 0.335 & 0.283 & 0.416 & 0.008 & 0.470 & 0.016 & $<0.001$ \\
trans-MUFA & 0.136 & 0.101 & 0.237 & 0.006 & 0.149 & 0.005 & 0.143 \\
$9 t-18: 1$ & 0.0970 & 0.0680 & 0.117 & 0.0026 & 0.0625 & 0.0026 & $<0.001$ \\
\hline
\end{tabular}

Min, minimum value; Max, maximum value; SEM, standard error of the mean. MUFA, monounsaturated fatty acids. (FA).

Table 4. Effect of fat tissue (muscle and subcutaneous fat) on the conjugated and non-conjugated diene, triene, polyunsaturated fatty acid and dimethylacetal composition of horse meat in percentage basis $(\%)(n=20)$.

\begin{tabular}{cccccccc}
\hline & \multicolumn{9}{c}{ Muscle } & \multicolumn{3}{c}{ Subcutaneous } & \multirow{2}{*}{-Value } \\
\cline { 2 - 6 } & Mean & Min & Max & SEM & Mean & SEM & \\
\hline CLA (18:2) & 0.118 & 0.0884 & 0.198 & 0.007 & 0.0931 & 0.0050 & 0.008 \\
9c,11t- & 0.0535 & 0.0394 & 0.0712 & 0.0022 & 0.0581 & 0.0043 & 0.318 \\
NC-dienes (18:2) & 0.0605 & 0.0372 & 0.1002 & 0.0033 & 0.0475 & 0.0030 & 0.008 \\
Trienes (18:3) & 0.0220 & 0.0073 & 0.0371 & 0.0016 & 0.0263 & 0.0020 & 0.099 \\
PUFA & 15.0 & 11.1 & 21.6 & 0.7 & 15.6 & 0.5 & 0.455 \\
20:3n-9 & 0.0263 & 0.0174 & 0.0441 & 0.0019 & 0.0125 & 0.0014 & $<0.001$ \\
n-6 & 11.7 & 8.76 & 19.38 & 0.7 & 12.5 & 0.6 & 0.424 \\
18:2n-6 & 10.1 & 7.55 & 16.6 & 0.6 & 12.0 & 0.5 & 0.026 \\
20:2n-6 & 0.206 & 0.141 & 0.335 & 0.012 & 0.281 & 0.012 & $<0.001$ \\
20:3n-6 & 0.240 & 0.124 & 0.387 & 0.015 & 0.0338 & 0.0022 & $<0.001$ \\
20:4n-6 & 0.946 & 0.491 & 1.74 & 0.071 & 0.0631 & 0.0053 & $<0.001$ \\
22:4n-6 & 0.0705 & 0.0381 & 0.160 & 0.0067 & 0.0194 & 0.0021 & $<0.001$ \\
22:5n-6 & 0.0470 & 0.266 & 0.793 & 0.0054 & ND & - & - \\
n-3 & 3.19 & 2.05 & 5.31 & 0.21 & 3.18 & 0.23 & 0.975 \\
18:3n-3 & 2.26 & 1.11 & 4.14 & 0.19 & 2.98 & 0.21 & 0.018 \\
20:3n-3 & 0.110 & 0.0720 & 0.188 & 0.007 & 0.106 & 0.008 & 0.714 \\
20:5n-3 & 0.125 & 0.0480 & 0.296 & 0.0134 & 0.0119 & 0.0010 & $<0.001$ \\
22:5n-3 & 0.503 & 0.266 & 0.793 & 0.027 & 0.0561 & 0.0034 & $<0.001$ \\
22:6n-3 & 0.115 & 0.0460 & 0.187 & 0.0084 & 0.0120 & 0.0010 & $<0.001$ \\
n-6/n-3 & 3.97 & 2.06 & 8.77 & 0.38 & 4.30 & 0.45 & 0.565 \\
P/S & 0.386 & 0.284 & 0.587 & 0.020 & 0.399 & 0.016 & 0.609 \\
DMA & 2.63 & 1.531 & 3.472 & 0.11 & ND & - & - \\
\hline
\end{tabular}

Min, minimum value; Max, maximum value; SEM, standard error of the mean. CLA, conjugated linoleic acids NC, non-conjugated; PUFA, polyunsaturated fatty acids; DMA, dimethylacetals (sum of DMA, AME (alk-1-enyl methyl ethers) and ALD (fatty aldehydes)); ND, not detected.

Considering the saturated fraction of muscle lipids (Tables 1 and 2), the obtained results (333-1743 mg/100 g of meat; 38.9\%) were in accordance with those reported in horse meat [3]. Palmitic acid (16:0) was the major FA (29.3\%) followed far behind by stearic (18:0) and myristic (14:0) acids (4.79\% and 3.65\%, respectively). The rest of minor SFA altogether constituted approximately only $1 \%$ of the total SFA.

Traditionally, BCFAs have not been discussed in horse meat studies since they are primarily associated to ruminant derived products due to their microbial origin [14]. 
However, they were described in tissues of other herbivores, such as rabbits, with microbial fermentation in the hindgut [65], which is also the case of horses. In this sense, recent studies have reported low contents of BCFAs in horse meat $(6.25 \mathrm{mg} / 100 \mathrm{~g}$ of meat) [5,61], in line with the present study $(4.98 \mathrm{mg} / 100 \mathrm{~g}$ of meat). The major BCFA in these studies was iso$16: 0$ and this is also supported by the present results ( $42 \%$ of total BCFA) (Tables 1 and 2 ).

Regarding monounsaturated FAs (MUFA), the absolute content ranged between 380 and $1877 \mathrm{mg} / 100 \mathrm{~g}$ meat, comprising 42.9\% of total FAMEs (Tables 1 and 3). This value locates among those reported in the literature for extensively reared $(14.6 \%)$ and concentrate fed (50.2\%) horses slaughtered at different ages [3]. Cis(c)-MUFAs represented 99.7\% of MUFAs, with oleic $(9 c-18: 1)$, palmitoleic $(9 c-16: 1)$ and ascleptic (11c-18:1) acids being the most abundant. Trans ( $t$-MUFAs have not been generally reported in horse meat studies $[6,8,62,66,67]$ as it is known that their content is low compared to ruminant products. The low accumulation of these FAs in equids is related to their digestive physiology [12,13]. In the present study, $t$-MUFA accounted only for $0.32 \%$ of total MUFA, with elaidic acid ( $9 t$ 18:1) being the major $t$-MUFA. CLAs are also minor in horse meat compared to ruminants, as they are primarily produced from PUFA by the action of rumen microbiota. However, as previously discussed, a low accumulation of these compounds is possible. In the present study, the total CLA represented $0.12 \%$ and similar percentages have been reported by $\mathrm{He}$ et al. [6] in 3 year old Breton horses fattened for 12 months $(0.15 \%)$ and by Belaunzaran et al. [61] in fattened and suckling crossbred horses $(0.11 \%)$. In contrast, higher proportions have reported Juarez et al. [62] in 24 month old Hispano-Bretón and Burguete horses $(0.42 \%)$ and by Lanza et al. [7] in 18 month old Sanfratello and Haflinger horses (0.46\%), which could well be related to the higher muscle fat content but also to the overestimation of CLA, taking into account that 21:0 elutes in the CLA region (GC technique). Rumenic acid $(9 c, 11 t-18: 2)$ was the major CLA isomer and in relation to non-conjugated (NC) dienes and trienes, their contribution was minor $(<0.1 \%)$ as reported by Belaunzaran et al. [61].

In general, horse meat has been described as rich in PUFAs (specially in essential linoleic (LA, 18:2n-6) and linolenic (LNA, 18:3n-3) acids) because, as discussed earlier, the FA absorption in the equine digestive system happens before the fermentative chambers, allowing an efficient absorption and deposition of dietary PUFAs in horse products with little transformation [3]. An average PUFA content of $345 \mathrm{mg} / 100 \mathrm{~g}$ of meat was found, accounting for $15.0 \%$ (Tables 1 and 4 ). This percentage was low compared to other studies reporting values from $15.6 \%$ in 3 year old concentrate-fed Breton horses [6] to $46 \%$ in 2 year old grass fed Galician Mountain horses [66]. The low PUFA content related to the low n-6 content, especially LA that is the major n-6 PUFA (86\% of total n-6 PUFA). On average, LA accounted for $10.1 \%$ of total FAMEs, a percentage that is below those usually reported in horses slaughtered at similar ages and managed under semiextensive (20.9-21\%, [7]; 16.6-18.9\%, [63]) systems. However, similar values to the present study were obtained by Lorenzo et al. [68], in a study performed with semi-extensively reared 18 month old Galician Mountain $\times$ Hispano-Bretón horses (10.1\%). Thus, the high-grain finishing period of the animals probably caused a remarkable decrease in LA percentage in favor of MUFAs. Regarding the rest of n-6 PUFAs, arachidonic acid (20:4n-6) was the second most abundant, in good agreement with previous works [5,7,18,66-68].

The capacity of horses to absorb dietary PUFAs before microbial hydrogenation has been related to the high accumulation of n-3 PUFAs from pastures (rich in LNA, 18:3n-3) [3]. More recently, as reviewed by Sahaka et al. [9], a specific pancreatic enzyme (pancreatic lipase related protein 2) hydrolyzing the LNA esterified in plant galactolipids has been described to be uniquely present in horse, contributing to LNA deposition in horse tissues. In the scientific literature, n-3 values from $1.53 \%$ in 36 month old Hispano-Bretón horses finished on concentrate for 12 months [18] up to $24.4 \%$ in 9 month old extensively reared Galician Mountain horses [69] have been reported, being diet the main source of variation and LNA the main responsible for those elevated n-3 contents. In the present study, an average value of $3.19 \%$ of $n-3$ PUFA (78 mg/100 $\mathrm{g}$ of meat) was observed, evidencing that the high-grain finishing limited the n-3 PUFA deposition. On average, LNA accounted 
for $2.26 \%$ and the next major n-3 PUFAs were 22:5n-3 (docosapentaenoic acid, DPA), 20:5n-3 (eicosapentaenoic acid, EPA), 22:6n-3 (docosahexaenoic acid, DHA) and 20:3n-3. These four FAs, although being cell membrane components, are seldom reported in horse meat studies.

Overall, obtained n-3 percentage was similar to the ones typically described in non $\mathrm{n}-3$ enriched chicken $(3.03 \%,[70])$ or rabbit $(3.40 \%,[71])$ and higher than non $\mathrm{n}-3$ enriched pork (1.22\% vs. $8.94 \%$ in $10 \%$ flaxseed enriched pork [72]).

Alkenyl moieties from plasmalogenic lipids in horse meat have not received much attention, although they have been studied in other meats [73,74]. The explanation for this may lie in the technical difficulties to resolve these compounds [15]. Under the conditions of the present study (acid-catalyzed methanolysis), these were detected as the sum of dimethylacetals, alk-1-enyl methyl ethers and fatty aldehydes. An average content of $60.3 \mathrm{mg} / 100 \mathrm{~g}$ of meat was found, in line with other horse meat studies [15,61]. These findings should not be diminished and deserve further research due to the increasing reports concerning the biological activities of plasmalogenic lipids and their relationship with human health $[16,17]$.

The results of the statistical analysis showed several significant differences in the FA content between muscle and SC fat (Tables 2-4). SC tissue showed significantly higher SFA content than muscle fat as the former is mainly composed of triacylglycerols, major components of neutral lipids that, in general, exhibit low PUFA and high SFA and MUFA depositions [61]. Conversely, 18:0 showed significantly higher content in muscle than in SC fat as observed by Belaunzaran et al. [5], which justified this phenomenon proving that this FA is mainly esterified in polar lipids [61]. Regarding MUFAs, significant differences were observed in several individual FAs and oleic acid (9c-18:1) was found in higher percentages in SC fat. In the literature, higher MUFA contents have been reported in SC compared to muscle fat $[5,62,63]$. Finally, no difference was observed in total PUFA content between the tissues although most long-chain n-6 and n-3 PUFAs were significantly higher in muscle compared to SC fat. In line with this, Belaunzaran et al. [61] described FA deposition preferences in horse muscle, indicating that all PUFAs were more abundant in polar lipids (phospholipids) except LNA that was preferentially deposited in neutral lipids (triacylglycerols).

\subsection{Effect of Ageing on Horse Meat Quality Parameters}

Ageing time significantly affected all the quality parameters $(\mathrm{pH}$, instrumental color, cook loss, WBSF; Table 5). Additionally, the statistical analysis revealed that slaughter day (five consecutive weeks) and its interaction with ageing time were also significant for some of the quality parameters studied, which could be attributed to other preslaughter factors affecting the oxidation state and color [75-77], texture and other quality attributes of meat [78]. However, when the interaction term was statistically significant, it was ordinal for all parameters and its effect size (measured by $\eta^{2}$ ) was smaller than the main effect (ageing time), except for $\mathrm{pH}$ measurements. In this case, the interaction between ageing time and slaughter day evidenced the effect of other uncontrolled preslaughter factors (Figure 1). 
Table 5. Statistical parameters on the effect of ageing time $(0,7,14$ and 21 days), slaughter day (5 consecutive weeks) and ageing time*slaughter day on $\mathrm{pH}$, instrumental color $\left(L^{*}, a^{*}, b^{*}, C^{*}, h^{*}\right)$, cook loss $(\%)$ and Warner-Bratzler shear force $(\mathrm{N})$ measurements in horse longissimus thoracis and lumborum muscle $(n=20)$.

\begin{tabular}{ccccccc}
\hline & \multicolumn{2}{c}{ AT } & & D & \multicolumn{2}{c}{ AT D $^{*}$} \\
\cline { 2 - 7 } & $p$-Value & $\eta^{2}$ & $p$-Value & $\eta^{2}$ & $p$-Value & $\eta^{2}$ \\
\hline $\mathrm{pH}$ & $<0.001$ & 0.583 & $<0.001$ & 0.758 & $<0.001$ & 0.796 \\
$L^{*}$ & $<0.001$ & 0.884 & 0.001 & 0.348 & $<0.001$ & 0.586 \\
$a^{*}$ & $<0.001$ & 0.665 & 0.015 & 0.251 & 0.319 & 0.254 \\
$b^{*}$ & $<0.001$ & 0.858 & 0.067 & 0.185 & 0.025 & 0.394 \\
$C^{*}$ & $<0.001$ & 0.718 & 0.024 & 0.230 & 0.230 & 0.278 \\
$h^{*}$ & $<0.001$ & 0.923 & 0.041 & 0.207 & $<0.001$ & 0.558 \\
Cook loss & 0.007 & 0.246 & 0.004 & 0.297 & 0.577 & 0.200 \\
WBSF & $<0.001$ & 0.926 & $<0.001$ & 0.684 & 0.114 & 0.321 \\
\hline
\end{tabular}

$\mathrm{T}$, ageing time; $\mathrm{D}$, slaughter day; $\eta^{2}$, eta square; WBSF, Warner-Bratzler shear force.

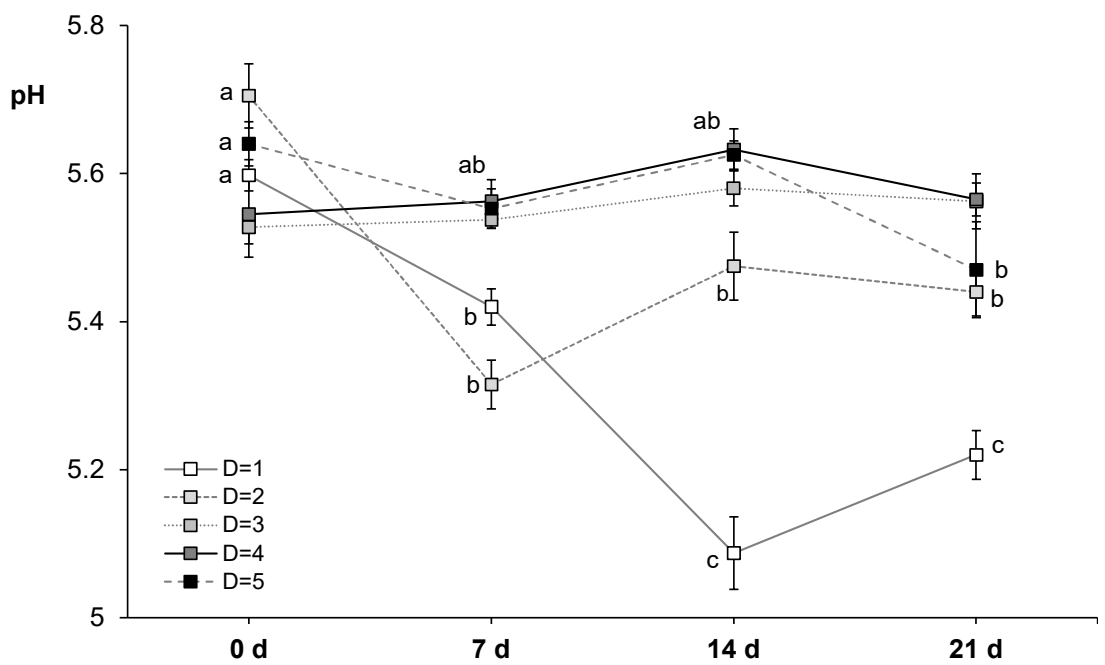

Figure 1. Interaction between ageing time $(0,7,14$ and 21 days) and slaughter day (D; 5 consecutive weeks) for $\mathrm{pH}$ measurements in horse longissimus thoracis and lumborum muscle $(n=20)$. Mean values and standard error of the means have been represented. Different letters indicate significant differences $(p \leq 0.05)$ among ageing times.

\subsubsection{Measurement of $\mathrm{pH}$}

Initial $\mathrm{pH}$ value measured at $48 \mathrm{~h}$ post mortem $(5.60 \pm 0.09)$ was similar to that reported by others $[23,59,60,62]$ in horse loins of Hispano-Bretón, Galician Mountain, Burguete and Jeju breeds, respectively. This would mean that a normal acidification was achieved during post mortem metabolism. In the literature, defects coming from abnormal post mortem metabolism have not been reported in horse meat $[22,79]$. The reason of $\mathrm{pH}$ value being slightly lower than the one typically registered in beef $[80,81]$ could be related to the higher glycogen content reported in horse meat compared to beef [79], after rigor completion it would store more residual glycogen and give lower $\mathrm{pH}$ values. During the ageing period, in general, $\mathrm{pH}$ values decreased from 0 to $7 \mathrm{~d}$ (mean value of 5.48) and, then, stayed stable until the end of the experiment ( $21 \mathrm{~d}$ ), except for the first slaughter day that values continued decreasing until $14 \mathrm{~d}$ (Figure 1). The reason for this behavior is not immediately apparent but it is likely attributed to other non-controlled factors. Related to $\mathrm{pH}$ decrease under vacuum, growth of lactic acid bacteria (LAB) has been reported to be the main responsible for $\mathrm{pH}$ decrease in refrigerated meats $(\mathrm{pH}<5.8$; [32]). Gomez and Lorenzo [38] reported a slight increase of LAB in vacuum packed horse meat during the first $7 \mathrm{~d}$ of ageing, without developing spoilage odors that could be the reason for the $\mathrm{pH}$ decrease 
during vacuum ageing. In contrast, Seong et al. [23] observed an increase of pH until $20 \mathrm{~d}$ of ageing, whereas others reported $\mathrm{pH}$ increases during the first 2 weeks of ageing $[38,40]$.

\subsubsection{Myoglobin Content and Instrumental Color}

Myoglobin content in meat is highly relevant as it determines meat color via its four chemical forms [82]. In particular, horse meat has been described as rich in myoglobin compared with other meats [83]. The chemistry of myoglobin is species specific [33]. In this sense, a high ability of oxygen to combine with the red oxymyoglobin and convert to brown metmyoglobin has been described in horse meat, affecting to the shelf life of meat [84]. The results obtained in the present study $(3.47 \mathrm{mg} / 100 \mathrm{~g}$ of meat) were comparable with values reported in extensively reared horses slaughtered at similar age $[63,84]$, but higher than those found in animals slaughtered at earlier ages [21], which is in accordance with what Badiani and Manfredini [83] indicated, that myoglobin content in horses increases during the first two years of life.

Regarding instrumental color parameters (Figure 2$)$, lightness $\left(L^{*}\right)$ values of the loin (40.8-45.1) were consistent with the literature [21,40]. However, others have reported lower (28-35 [62]; 35-37 [23]; 32-37 [85]) and higher (49-52 [84]) $L^{*}$ values in horses slaughtered at a similar age. In the present study, lightness significantly increased during the ageing period $(p \leq 0.001)$ with no changes among 7 and $14 \mathrm{~d}$ (Figure 2A). Lightness values reported during vacuum ageing in horse meat studies showed diverse patterns. For instance, Lorenzo and Gomez [40] and Seong et al., [23] did not observe any difference during the first $14 \mathrm{~d}$ and $30 \mathrm{~d}$ of ageing, respectively, while Ruiz [41] reported increased loin $L^{*}$ values when 13 month old horses were fed linseed enriched concentrate compared to regular concentrate. Overall, according to literature, $L^{*}$ values are not supposed to vary much during post mortem storage, showing only slight increases [86], which is due to changes in light scattering associated to muscle fibers shrinkage and fluids expulsion to the extracellular space [87].
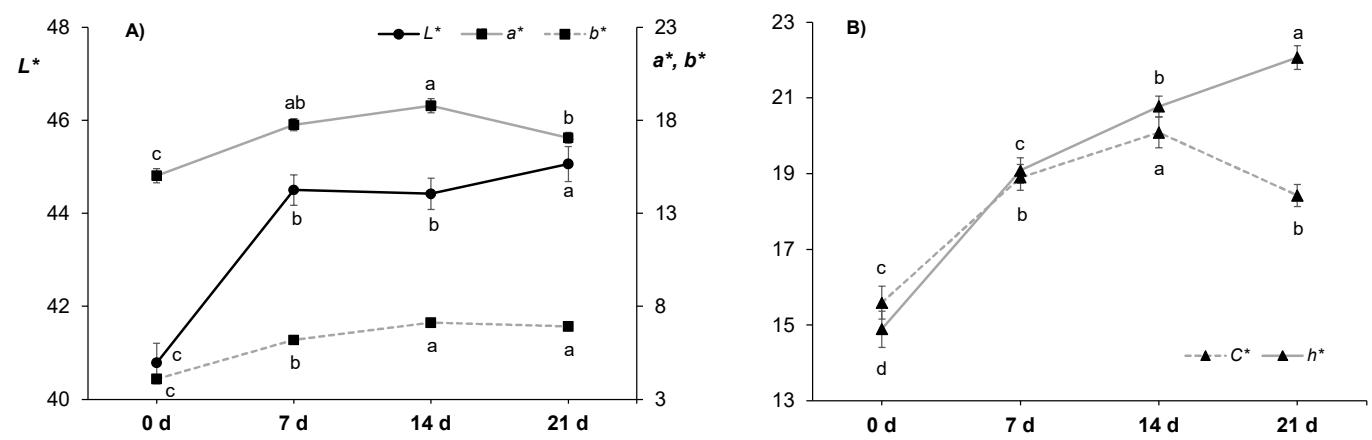

Figure 2. Effect of ageing time $(0,7,14$ and 21 days) on instrumental color measurements in horse longissimus thoracis and lumborum muscle $(n=20)$ : (A) $L^{*}$ (left axis), $a^{*}$ and $b^{*}$ (right axis), and (B) $C^{*}$ and $h^{*}$. Different letters indicate statistically significant differences $(p \leq 0.05)$.

Redness $\left(a^{*}\right)$ values (15.0-18.8; Figure 2A) were in good agreement with those reported by others in horse loins [23,38,40,62], although others reported lower values [21,84]. These variations in redness could be attributed to the total myoglobin content [63] that depends primarily on animal age [83]. Regarding the ageing time, redness was the highest at $14 \mathrm{~d}$ (18.8) and the lowest (15.0) in non-aged loins, whereas at $7 \mathrm{~d}$ and $21 \mathrm{~d}$ intermediate values were observed. A significant increase in redness from 0 to $14 \mathrm{~d}$ in vacuum aged meat was also observed by Lorenzo and Gomez [40] while Seong et al. [23] reported a continuous increasing trend up to $30 \mathrm{~d}$.

Yellowness $\left(b^{*}\right)$ values (4.09-7.12; Figure 2A) were similar to some $[20,21,23]$ but lower compared to other horse meat studies (12-14 [38]; 10-14 [40]; 8-15 [84]) and these variations could be attributed to differences in muscle fat content and slaughter age of horses [63]. In the present study, during ageing time, $b^{*}$ values increased from $4.09(0 \mathrm{~d})$ to $7.12(14 \mathrm{~d})$ 
while no difference was found between 14 and $21 \mathrm{~d}$. Gomez and Lorenzo [38] and Lorenzo and Gomez [40] also observed an increase in yellowness during vacuum storage that plateaued at 7 and $10 \mathrm{~d}$, respectively, while Seong et al. [23] reported an increase in $b^{*}$ values over during $30 \mathrm{~d}$ of ageing.

In terms of calculated chroma $\left(C^{*}\right)$ and hue $\left(h^{*}\right)$ values, the decrease observed in redness but not in yellowness between 14 and $21 \mathrm{~d}$ resulted in a significant increase of hue value from 20.8 to 22.1 (Figure $2 \mathrm{~B}$ ) in the yellow $\left(+b^{*}\right)$ direction of the CIELAB color space. This happened together with a decrease in chroma $\left(C^{*}\right)$ from 20.1 to 18.4 , being recognized as a more grey or dull color (dull yellow) perceived as brown. This would indicate that horse meat started to turn brownish between 14 and $21 \mathrm{~d}$ of ageing due to metmyoglobin formation $[28,86]$. The color changes during ageing period are well illustrated in Figure 3, where a representative photograph of each ageing time is shown. It is worth commenting that samples aged for $21 \mathrm{~d}$ were visually evaluated by 120 consumers and these samples obtained the worst acceptability scores [43]. After $14 \mathrm{~d}$ of ageing, the visually apparent color shift to brownish could be the reason why consumers rejected the meat aged for $21 \mathrm{~d}$, as the cherry-red color that they associate with freshness was not present [88].

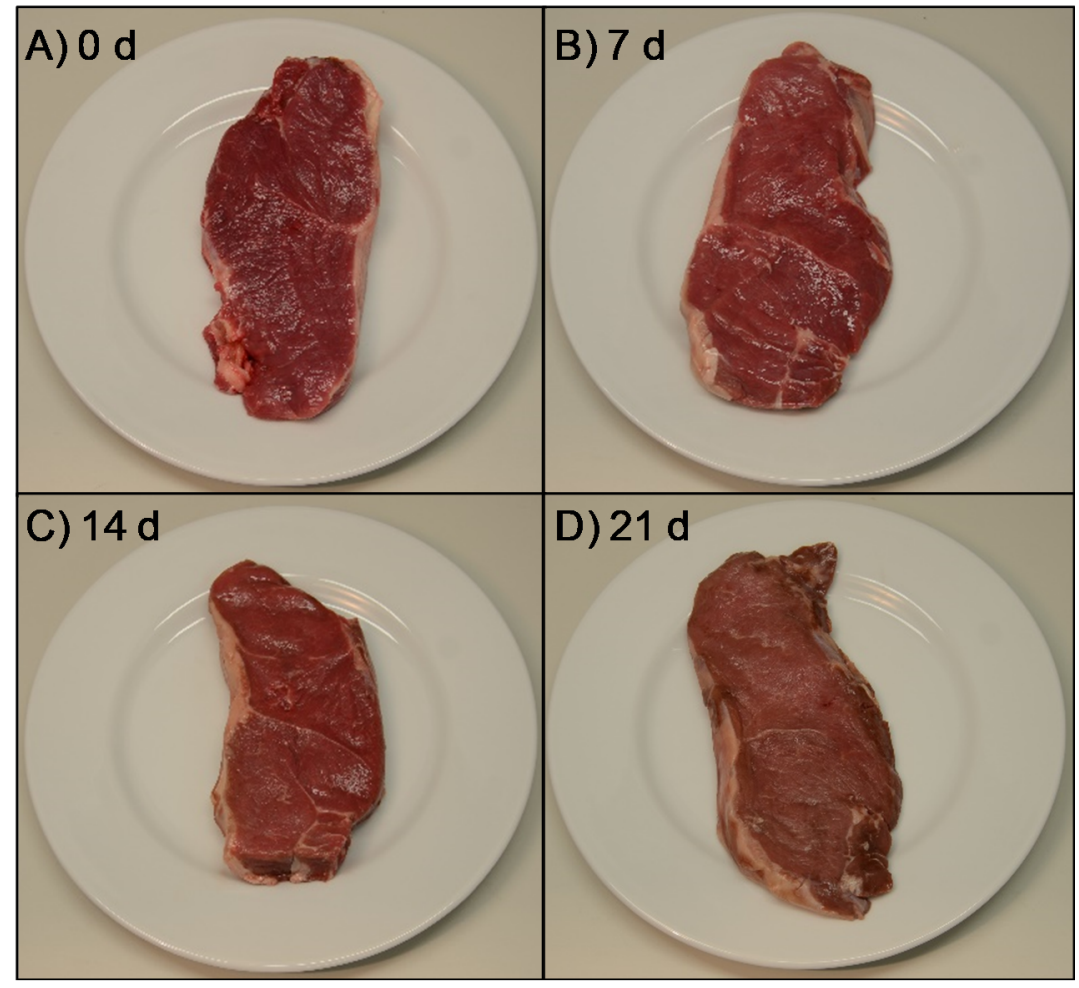

Figure 3. Representative photographs of non-aged (A) and aged horse longissimus thoracis and lumborum steaks ((B) 7 days, (C) 14 days and (D) 21 days).

\subsubsection{Cook Loss and Instrumental Texture}

It is known that cooking contributes to meat texture changes, while moisture and cook losses happen in a time and temperature dependent manner [89]. Cook loss values ranged between 20.3 and $23.0 \%$ (Figure 4). The value obtained in non-aged horse meat $(23 \%$ ) was similar to those values reported by others in cooked horse loins [23,39]. Values decreased from non-aged to $7 \mathrm{~d}$ aged meat (20.3\%) and then stayed constant. It is known that ageing affects water distribution and mobility in meat [90] but contradictory results have been reported in the literature regarding cook loss data. In some studies, an increase in cook loss with ageing has been observed as a result of a weakened muscle structure unable to trap or retain water [87] while in others a decrease has been reported as a result of a lower initial water content related to a $\mathrm{pH}$ drop [91,92]. The second statement seem to better explain the results of the present study as a decrease in both $\mathrm{pH}$ and cook loss happened between 
0 and $7 \mathrm{~d}$ of ageing (Figures 1 and 4). In the scientific literature, Seong et al. [23] did not observe any differences in cook loss during $30 \mathrm{~d}$ ageing whereas Kaic et al. [39] reported an increase in cook loss from 14 to $28 \mathrm{~d}$ of horse meat ageing. Overall, only few studies have reported cook loss data in horse meat and the variability of results is considerable.

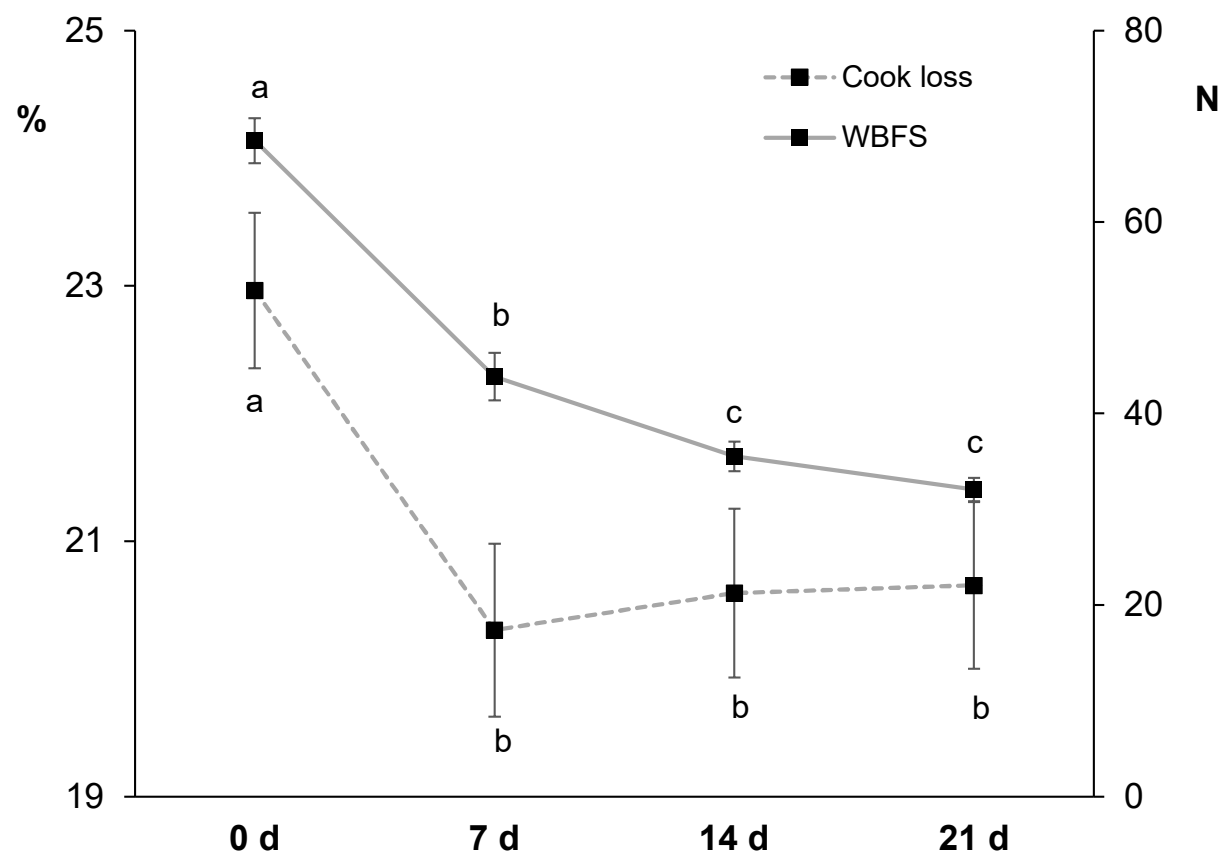

Figure 4. Effect of ageing time (0,7,14 and 21 days) on cook loss (left axis) and Warner-Bratzler shear force (WBSF; right axis) in horse longissimus thoracis and lumborum muscle $(n=20)$. Different letters indicate statistically significant differences $(p \leq 0.05)$.

Regarding instrumental texture measured in cooked horse meat, values ranged between 32.1 and $68.5 \mathrm{~N}$ (Figure 4). The WBSF value in non-aged horse loin $(68.5 \mathrm{~N})$ was higher than values reported in the literature ( $40 \mathrm{~N}$ [23]; $31 \mathrm{~N} \mathrm{[37])} \mathrm{but} \mathrm{close} \mathrm{to} \mathrm{values} \mathrm{re-}$ ported in 4-6 d aged meat from 18 month old Sanfratellano and Haflinger horses (56.5 N [7]), in $2 \mathrm{~d}$ aged meat from 10 year old horses (63 N [22]), and in non-aged meat from 13 and 26 month old Galician Mountain $\times$ Burguete horses (52.5 N [41]). In the present study, as expected, WBSF values decreased significantly from $0(68.5 \mathrm{~N})$ to $14 \mathrm{~d}(35.5 \mathrm{~N})$, with no additional significant changes ( $32.1 \mathrm{~N}$ at $21 \mathrm{~d}$ ). Considering the WBSF-dependent classification proposed by Shackelford, Morgan, Cross and Savell [93] for beef loin as there is no homologous classification for horse meat, non-aged meat would be classified as 'tough', $7 \mathrm{~d}$ aged meat as 'intermediate', and $14 \mathrm{~d}$ and $21 \mathrm{~d}$ aged meat as 'tender'. In essence, due to expected post mortem proteolysis [30], ageing period improved meat tenderness, especially during the first two weeks. Similarly, Seong et al. [23] observed a decrease in WBSF values during the first $10 \mathrm{~d}$ of ageing (getting classified as 'very tender') in meat from 28 month old Jeju horses. Some other horse meat studies have reported earlier tenderization; for instance, Della Malva et al. [37] reported the most tender horse meat after only $3 \mathrm{~d}$ of ageing and they did not perceive any additional changes thereafter. Others have reported significant improvement of WBSF values after 4 and $8 \mathrm{~d}$ of ageing depending on animal feeding and age [41].

\section{Conclusions}

The fatty acid composition of Hispano-Bretón horse meat characterized in the present study indicated that the high-grain finishing period may have limited the deposition of polyunsaturated fatty acids in tissues, especially of n-3, compared to values typically described in grazing horses. However, obtained n-3 polyunsaturated fatty acid contents were still higher than those generally reported in ruminant derived products although LNA 
was preferentially deposited in backfat compared to muscle fat, confirming the potential of horse as an interesting red meat alternative in terms of its nutritional quality. The present study highlights that the ageing process affects horse meat quality parameters that are very relevant for the consumer. Visual properties started to deteriorate after 14 days of ageing and the improvement in tenderness also happened during the first 14 days, although meat could be considered as 'intermediate tender' after the first week of ageing. From the results obtained, the optimum ageing time can be established between 7 and 14 days for Hispano-Bretón horse meat; longer periods would not be justified from the quality point of view nor from the economic point of view. All in all, further research is required in order to standardize post mortem practices so as to obtain homogeneous final horse meat quality.

Author Contributions: Conceptualization, N.A., L.R.B. and L.M.; methodology, L.R.B., L.M. and K.I.; software, L.R.B. and L.J.R.B.; validation, L.R.B., L.M. and N.A.; formal analysis, L.R.B., L.M., K.I. and N.A.; investigation, L.R.B. and N.A.; resources, L.J.R.B.; data curation, L.R.B. and L.J.R.B.; writing-original draft preparation, L.R.B. and L.M.; writing-review and editing, N.A., M.Á.S., L.J.R.B. and K.I.; visualization, L.M. and N.A.; supervision, N.A. and M.Á.S.; project administration, N.A.; funding acquisition, L.J.R.B. and N.A. All authors have read and agreed to the published version of the manuscript.

Funding: This research was funded by the Basque Government (grant IT944-16) that also funded the postdoctoral grant of L.M. Department of Economic Development and Infrastructures of the Basque Government is acknowledged for the fellowship of L.R.B.

Institutional Review Board Statement: Not applicable, as commercial samples were studied.

Data Availability Statement: The data presented in this study are available on request from the corresponding author.

Conflicts of Interest: The authors declare no conflict of interest. The funders had no role in the writing of the manuscript.

\section{References}

1. Rossier, E. Horse meat. In Encyclopedia of Food Sciences and Nutrition; Caballero, B., Trugo, L., Finglas, P., Eds.; Academic Press: Cambridge, UK, 2003; pp. 3174-3178.

2. Ursin, L. The Ethics of the Meat Paradox. Environ. Ethics 2016, 38, 131-144. [CrossRef]

3. Belaunzaran, X.; Bessa, R.J.B.; Lavín, P.; Mantecón, A.R.; Kramer, J.K.G.; Aldai, N. Horse-meat for human con-sumption-Current research and future opportunities. Meat Sci. 2015, 108, 74-81. [CrossRef]

4. Del Bò, C.; Simonetti, P.; Gardana, C.; Riso, P.; Lucchini, G.; Ciappellano, S. Horse meat consumption affects iron status, lipid profile and fatty acid composition of red blood cells in healthy volunteers. Int. J. Food Sci. Nutr. 2012, 64, 147-154. [CrossRef]

5. Belaunzaran, X.; Lavín, P.; Barron, L.J.; Mantecón, A.R.; Kramer, J.K.; Aldai, N. An assessment of the fatty acid composition of horse-meat available at the retail level in northern Spain. Meat Sci. 2017, 124, 39-47. [CrossRef] [PubMed]

6. He, M.L.; Ishikawa, S.; Hidari, H. Fatty Acid Profiles of Various Muscles and Adipose Tissues from Fattening Horses in Comparison with Beef Cattle and Pigs. Asian-Australas. J. Anim. Sci. 2005, 18, 1655-1661. [CrossRef]

7. Lanza, M.; Landi, C.; Scerra, M.; Galofaro, V.; Pennisi, P. Meat quality and intramuscular fatty acid composition of Sanfrantellano and Haflinger foals. Meat Sci. 2009, 81, 142-147. [CrossRef]

8. Pinto, F.; Schiavone, M.; Marisco, G. Effects of diets containing $\omega 3$ fatty acids on productive performances and meat quality of "Murguese" foals. Prog. Nutr. 2004, 6, 122-131.

9. Sahaka, M.; Amara, S.; Wattanakul, J.; Gedi, M.; Aldai, N.; Parsiegla, G.; Lecomte, J.; Christeller, J.T.; Gray, D.; Gontero, B.; et al. The digestion of galactolipids and its ubiquitous function in nature for the uptake of the essential $\alpha$-linoleic acid. Food Funct. 2020, 11, 6710-6744. [CrossRef]

10. Santos, A.S.; Rodrigues, M.A.M.; Bessa, R.J.B.; Ferreira, L.M.; Martin-Rosset, W. Understanding the equine ce-cum-colon ecosystem: Current knowledge and future perspectives. Animal 2011, 5, 48-56. [CrossRef]

11. Clauss, M.; Grum, C.; Hatt, J. Polyunsaturated fatty acid content in adipose tissue in foregut and hindgut ferment-ing mammalian herbivores: A literature survey. Mamm. Biol. 2009, 74, 153-158. [CrossRef]

12. Hartman, L.; Shorland, F.B.; Moir, R.J.; Hartman, F.B.S.L. Occurrence of trans-Unsaturated Fatty Acids in Horse Fæces. Nat. Cell Biol. 1956, 178, 1057-1058. [CrossRef]

13. McKain, N.; Shingfield, K.J.; Wallace, R.J. Metabolism of Conjugated Linoleic Acids and 18:1 fatty acids by rumi-nal bacteria: Products and mechanism. Microbiology 2010, 156, 579-588. [CrossRef] [PubMed]

14. Vlaeminck, B.; Fievez, V.; Cabrita, A.; Fonseca, A.; Dewhurst, R. Factors affecting odd- and branched-chain fatty acids in milk: A review. Anim. Feed. Sci. Technol. 2006, 131, 389-417. [CrossRef] 
15. Delmonte, P.; Belaunzaran, X.; Ridge, C.D.; Aldai, N.; Kramer, J.K. Separation and characterization of products from acidic methanolysis of plasmalogenic lipids by two-dimensional gas chromatography with online reduction. J. Chromatogr. A 2020, 1619, 460955. [CrossRef]

16. Nagan, N.; Zoeller, R.A. Plasmalogens: Biosynthesis and functions. Prog. Lipid Res. 2001, 40, 199-229. [CrossRef]

17. Van der Veen, J.N.; Kenelly, J.P.; Wan, S.; Vance, J.E.; Vance, D.E.; Jacobs, R.L. The critical role of phosphatidyl-choline and phosphatidylethanolamine metabolism in health and disease. Biochim. Biophisica Acta 2017, 1859, 1558-1572. [CrossRef] [PubMed]

18. Sarriés, M.V.; Murray, B.E.; Troy, D.; Beriain, M.J. Intramuscular and subcutaneous lipid fatty acid profile compo-sition in male and female foals. Meat Sci. 2006, 72, 475-485. [CrossRef] [PubMed]

19. De Palo, P.; Maggiolino, A.; Centoducati, P.; Tateo, A. Slaughtering Age Effect on Carcass Traits and Meat Quality of Italian Heavy Draught Horse Foals. Asian-Australas. J. Anim. Sci. 2013, 26, 1637-1643. [CrossRef] [PubMed]

20. Duffey, P.A. Sensory and physico-chemical properties of meat form horses of different age groups. In Proceedings from the $42 n d$ International Congress of Meat Science and Technology; ICoMST: Lillehammer, Norway, 1996; pp. 556-557.

21. Franco, D.; Rodriguez, E.; Purriños, L.; Crecente, S.; Bermúdez, R.; Lorenzo, J.M. Meat quality of "Galician moun-tain" foals breed. Effect of sex, slaughter age and livestock production system. Meat Sci. 2011, 88, 292-298. [CrossRef]

22. Litwińczuk, A.; Florek, M.; Skałecki, P. Chemical composition and physicochemical properties of horse meat from the longissimus lumborum and semitendinosus muscle. J. Muscle Foods 2008, 19, 223-236. [CrossRef]

23. Seong, P.; Park, K.M.; Cho, S.; Kang, G.H.; Chae, H.S.; Park, B.Y.; Ba, H.V. Effect of cut type and post mortem ageing on technological quality, textural profile and sensory characteristics of foal meat. Anim. Prod. Sci. 2016, 56, 1551-1559. [CrossRef]

24. Warren, K.; Kastner, C. A comparison of dry-aged and vacuum-aged beef strip loins. J. Muscle Foods 1992, 3, 151-157. [CrossRef]

25. Laster, M.A.; Smith, R.D.; Nicholson, K.L.; Nicholson JD, W.; Harris, K.B.; Miller, R.K.; Griffin, D.B.; Savell, J.W. Dry versus wet aging of beef: Retail cutting yields and consumer sensory attribute evaluations of steaks from ri-beyes, strip loins, and top sirloins from two quality grade groups. Meat Sci. 2008, 80, 795-804. [CrossRef] [PubMed]

26. Kim YH, B.; Ma, D.; Setyabrata, D.; Farouk, M.M.; Lonergan, S.M.; Hyff-Lonergan, E.; Hunt, M.C. Understanding post-mortem biochemical processes and post-harvest ageing factors to develop novel smart-aging strategies. Meat Sci. 2018, 144, 74-90. [CrossRef]

27. Jeremiah, L. Packaging alternatives to deliver fresh meats using short- or long-term distribution. Food Res. Int. 2001, 34, 749-772. [CrossRef]

28. MacDougall, D.B. Principles of colour measurement for food. In Instru-Mentation and Sensors for the Food Industry; Kress-Rogers, E., Brimelow, C.J.B., Eds.; Woodhead Printing: Cambridge, UK, 2001; pp. 63-84.

29. Koohmaraie, M. Muscle proteinases and meat aging. Meat Sci. 1994, 36, 93-104. [CrossRef]

30. Ouali, A.; Gagaoua, M.; Boudida, Y.; Becila, S.; Boudjellal, A.; Herrera-Mendez, C.H.; Sentandreu, M.A. Biomarkers of meat tenderness: Present knowledge and perspectives in regards to our current understanding of the mechanisms in-volved. Meat Sci. 2013, 95, 854-870. [CrossRef] [PubMed]

31. Martínez-Cerezo, S.; Sañudo, C.; Panea, B.; Medel, I.; Delfa, R.; Sierra, I.; Beltrán, J.; Cepero, R.; Olleta, J. Breed, slaughter weight and ageing time effects on physico-chemical characteristics of lamb meat. Meat Sci. 2005, 69, 325-333. [CrossRef] [PubMed]

32. Gill, C. Extending the storage life of raw chilled meats. Meat Sci. 1996, 43, 99-109. [CrossRef]

33. Suman, S.P.; Joseph, P. Myoglobin Chemistry and Meat Color. Annu. Rev. Food Sci. Technol. 2013, 4, 79-99. [CrossRef]

34. Nair, M.N.; Canto, A.C.; Rentfrow, G.; Suman, S.P. Muscle-specific effect of aging on beef tenderness. LWT 2019, 100, 250-252. [CrossRef]

35. Hwang, S.; Hong, G. Effects of high pressure in combination with the type of ageing on the eating quality and bi-ochemical changes in pork loin. Meat Sci. 2020, 162, 108028. [CrossRef] [PubMed]

36. Callejas-Cárdenas, A.R.; Caro, I.; Blanco, C.; Villalobos-Delgado, L.H.; Prieto, N.; Bodas, R.; Giráldez, F.J.; Mateo, J.; García, J.G. Effect of vacuum ageing on quality changes of lamb steaks from early fattening lambs during aerobic display. Meat Sci. 2014, 98, 646-651. [CrossRef] [PubMed]

37. Della Malva, A.; De Palo, P.; Lorenzo, J.M.; Maggiolino, A.; Albenzio, M.; Marino, R. Application of proteomic to investigate the post-mortem tenderization rate of different horse muscles. Meat Sci. 2019, 157, 107885. [CrossRef] [PubMed]

38. Gómez, M.; Lorenzo, J.M. Effect of packaging conditions on shelf-life of fresh foal meat. Meat Sci. 2012, 91, 513-520. [CrossRef]

39. Kaić, A.; Žgur, S.; Luštrek, B.; Potočnik, K. Physicochemical properties of horse meat as affected by breed, sex, age, muscle type and aging period. Anim. Prod. Sci. 2018, 58, 2352-2357. [CrossRef]

40. Lorenzo, J.M.; Gómez, M. Shelf life of fresh foal meat under MAP, overwrap and vacuum packaging conditions. Meat Sci. 2012, 92, 610-618. [CrossRef]

41. Ruiz, M. Effect of Production Factors on Foal Carcass and Meat Quality. Consumers Preferences. Colour and Texture Evolution of Foal Meat during the Storage Time as Quality Attributes, from Animals Reared under Sustainable Conditions. Ph.D. Thesis, Public University of Navarre, Navarre, Spain, 2008.

42. Council Regulation. No 1099/2009 of 24 September 2009 on the protection of animals at the time of killing. Off. J. Eur. Union L 2009, 303, 1-30.

43. Beldarrain, L.R.; Etaio, I.; Morán, L.; Sentandreu, M.; Sentandreu, M.Á.; Barron, L.J.R.; Aldai, N. Effect of ageing time on consumer preference and sensory description of foal meat. Food Res. Int. 2020, 129, 108871. [CrossRef] 
44. Council Regulation. No 1208/81 of 28 April 1981 determining the community scale for the classification of carcasses of adult bovine animals. Off. J. Eur. Union L 1981, 123, 3-6.

45. International Organization for Standardization. Animal Feeding Stuffs: Determination of Moisture and Other Volatile Matter Content; Standard 6496:1999; International Organization for Standardization: Geneva, Switzerland, 1999.

46. International Organization for Standardization. Animal Feeding Stuffs-Determination of Nitrogen Content and Calculation of Crude Protein Content-Part 2: Block Digestion and Steam Distillation Method; International Standard ISO 5983-2:2005; International Organization for Standardization: Geneva, Switzerland, 2005.

47. American Oil Chemists' Society. Official Methods and Recommended Practices of the American Oil Chemists 'Society; American Oil Chemists' Society: Champaign, IL, USA, 2008.

48. International Organization for Standardization. Animal Feeding Stuffs-Determination of Crude Ash; Standard 5984:2002; International Organization for Standardization: Geneva, Switzerland, 2002.

49. Folch, J.; Lees, M.; Sloane-Stanley, G.H. A simple method for the isolation and purification of total lipides from animal tissues. J. Biol. Chem. 1957, 226, 497-509. [CrossRef]

50. Kramer, J.K.; Hernandez, M.; Cruz-Hernandez, C.; Kraft, J.; Dugan ME, R. Combining results of two GC separa-tions partly achieves determination of all cis and trans 16:1, 18:1, 18:2 and 18:3 except CLA isomers of milk fat as demon-strated using Ag-ion SPE fractionation. Lipids 2008, 43, 259-273. [CrossRef] [PubMed]

51. Belaunzaran, X.; Bravo-Lamas, L.; Kramer JK, G.; Aldai, N. Limitation of using silver ion solid-phase extraction for animal lipids with a low trans content. Eur. J. Lipid Sci. Technol. 2014, 116, 1621-1625. [CrossRef]

52. Belaunzaran, X.; Bravo-Lamas, L.; Kramer JK, G.; Morales, R.; Aldai, N. Silver ion solid-phase extraction car-tridges employing glass housings overcome the limitations observed in the GC analysis of animal lipids with low trans fatty acid content. Eur. J. Lipid Sci. Technol. 2017, 119, 1600124. [CrossRef]

53. Bravo-Lamas, L.; Barron LJ, R.; Kramer JK, G.; Etaio, I.; Aldai, N. Characterization of the fatty acid composition of lam commercially available in northern Spain: Emphasis on the trans-18:1 and CLA content and profile. Meat Sci. 2016, 117, 108-116. [CrossRef]

54. Wolff, R.L.; Bayard, C.C.; Fabien, R.J. Evaluation of sequential methods for the determination of butterfat fatty acid composition with emphasis on trans-18:1 acid. Application to the study of seasonal variations in French butters. J. Am. Oil Chem. Soc. 1995, 72, 1471-1483. [CrossRef]

55. Faustman, C.; Philips, A.L. Measurement of discoloration in fresh meat. In Current protocols in Food Analytical Chemistry; Wrostlad, R.E., Ed.; Wiley \& Sonspp: New York, NY, USA, 2001; pp. F3.3.1-F3.3.13.

56. Bowen, W.J. The absorption expectra and extinction coefficients of myoglobin. J.Biol. Chem. 1949, 179, 235-245. [CrossRef]

57. Comision Internationale de 1'Eclairage. Colorimetry: Official Recommendations of the International Commission on Illumintion; Comision Internationale de 1'Eclairage: Paris, France, 1976.

58. Honikel, K.O. Reference methods for the assessment of physical characteristics of meat. Meat Sci. 1998, 49, 447-457. [CrossRef]

59. Lorenzo, J.M.; Sarriés, M.V.; Franco, D. Sex effect on meat quality and carcass traits of foals slaughtered at 15 months of age. Animal 2013, 7, 1199-1207. [CrossRef]

60. Sarriés, M.; Beriain, M. Carcass characteristics and meat quality of male and female foals. Meat Sci. 2005, 70, 141-152. [CrossRef]

61. Belaunzaran, X.; Lavín, P.; Mantecón, A.R.; Kramer, J.K.G.; Aldai, N. Effect of slaughter age and feeding system on the neutral and polar lipid composition of horse meat. Animal 2018, 12, 417-425. [CrossRef]

62. Juarez, M.; Polvillo, O.; Gómez, M.D.; Alcalde, M.J.; Romero, F.; Valera, M. Breed effect on carcass and meat quali-ty of foals slaughtered at 24 months of age. Meat Sci. 2009, 83, 224-228. [CrossRef]

63. Tateo, A.; De Palo, P.; Ceci, E.; Centoducati, P. Physicochemical properties of meat of Italian Heavy Draft horses slaughtered at the age of eleven months1. J. Anim. Sci. 2008, 86, 1205-1214. [CrossRef] [PubMed]

64. Pannier, L.; Pethick, D.W.; Boyce, M.D.; Ball, A.; Jacob, R.H.; Gardner, G.E. Associations of genetic and non-genetic factors with concentrations of iron and zink in the longissimus muscle of lamb. Meat Sci. 2014, 96, 1111-1119. [CrossRef]

65. Leiber, F.; Meier, J.S.; Burger, B.; Wettstein, H.-R.; Kreuzer, M.; Hatt, J.-M.; Clauss, M. Significance of Coprophagy for the Fatty Acid Profile in Body Tissues of Rabbits Fed Different Diets. Lipids 2008, 43, 853-865. [CrossRef]

66. Guil-Guerrero, J.L.; Rincón-Cervera, M.A.; Venegas-Venegas, C.E.; Ramos-Bueno, R.P.; Suarez, M.D. Highly bi-oavailable $\alpha$-linolenic acid from the subcutaneous fat of the Palaeolithic Relict "Galician Horse". Int. Food Res. J. 2013, $20,3249-3258$.

67. Ferjak, E.; Cavinder, C.; Sukumaran, A.; Burnett, D.; Lemley, C.; Dinh, T. Fatty acid composition of mesenteric, cardiac, abdominal, intermuscular, and subcutaneous adipose tissues from horses of three body condition scores. Livest. Sci. 2019, 223, 116-123. [CrossRef]

68. Lorenzo, J.; Crecente, S.; Franco, D.; Sarriés, M.; Gómez, M. The effect of livestock production system and concentrate level on carcass traits and meat quality of foals slaughtered at 18 months of age. Animal 2014, 8, 494-503. [CrossRef] [PubMed]

69. Lorenzo, J.M.; Fuciños, C.; Purriños, L.; Franco, D. Intramuscular fatty acid composition of "Galician mountain" foals breed. Effect of sex, slaughtered age and livestock production system. Meat Sci. 2010, 86, 825-831. [CrossRef] [PubMed]

70. Ribiero, T.; Lordelo, M.M.; Alves, S.P.; Bessa, R.J.B.; Costa, P.; Lemos, J.P.C.; Ferreira, L.M.A.; Fontes, C.M.G.A.; Prates, J.A.M. Direct supplementation of diet is the most efficient way of enriching broiler meat with n-3 long chain poly-unsaturated fatty acid. Br. Poult. Sci. 2014, 54, 753-765. [CrossRef] 
71. Kouba, M.; Benatmane, F.; Blochet, J.; Mourot, J. Effect of a linseed diet on lipid oxidation, fatty acid composition of muscle, perirenal fat, and raw and cooked rabbit meat. Meat Sci. 2008, 80, 829-834. [CrossRef]

72. Dugan, M.E.; Vahmani, P.; Turner, T.D.; Mapiye, C.; Juárez, M.; Prieto, N.; Beaulieu, A.D.; Zijlstra, R.T.; Patience, J.F.; Aalhus, J.L. Pork as a Source of Omega-3 (n-3) Fatty Acids. J. Clin. Med. 2015, 4, 1999-2011. [CrossRef]

73. Aldai, N.; Lavín, P.; Kramer JK, G.; Jaroso, R.; Mantecón, A.R. Breed effect on quality veal production in moun-tain areas: Emphasis on meat fatty acid composition. Meat Sci. 2012, 92, 687-696. [CrossRef] [PubMed]

74. Enomoto, H.; Furukawa, T.; Takeda, S.; Hatta, H.; Zaima, N. Unique distribution of diacyl-, alkylacyl- and alkenylacylphosphatidylcholine species visualized in pork chop tissues by matrix-assisted laser desorp-tion/ionization-mass spectrometry imaging. Foods 2020, 9, 205. [CrossRef] [PubMed]

75. Delosiere, M.; Durand, D.; Bourget, C.; Terlow EM, C. Lipid oxidation, pre-slaughter animal stress and meat packaging: Can dietary supplementation of vitamin E and plant extracts come to rescue? Food Chem. 2020, 309, 125668. [CrossRef]

76. Ferguson, D.M.; Warner, R.D. Have we underestimated the impact of pre-slaughter stress on meat quality in ru-minants? Meat Sci. 2008, 80, 12-19. [CrossRef] [PubMed]

77. Young, J.F.; Rosenvold, K.; Stagsted, J.; Steffensen, C.L.; Nielsen, J.H.; Andersen, H.N. Significance of preslaugh-ter stress and different tissue PUFA levels in the oxidative status and stability of porcine muscle and meat. J. Agric. Chem. 2003, 51, 6877-6881. [CrossRef]

78. Gill, C. Safety and storage stability of horse meat for human consumption. Meat Sci. 2005, 71, 506-513. [CrossRef]

79. Lawrie, R.D. Metabolic stress which affect muscle. In The Physiology and Biochemistry of Muscle as a Food; Briskey, E.J., Cassens, R.G., Trautman, J.D., Eds.; University of Wisconsin Press: Madison, WI, USA, 1966; pp. 137-164.

80. Jelenikova, J.; Pipek PStaruch, L. The influence of ante-mortem treatment on relationship between $\mathrm{pH}$ and ten-derness of beef. Meat Sci. 2008, 80, 870-873. [CrossRef] [PubMed]

81. Wu, G.; Farouk, M.; Clerens, S.; Rosenvold, K. Effect of beef ultimate $\mathrm{pH}$ and large structural protein changes with aging on meat tenderness. Meat Sci. 2014, 98, 637-645. [CrossRef]

82. American Meat Science Association. Meat Colour Measurement Guidelines, Revised December 2012; American Meat Science Association: Champaign, IL, USA, 2012.

83. Badiani, A.; Manfredini, M. The production of horse meat. Ital. J. Anim. Sci. 1994, 19, 23-31.

84. Sarriés, M.; Beriain, M. Colour and texture characteristics in meat of male and female foals. Meat Sci. 2006, 74, 738-745. [CrossRef]

85. De Palo, P.; Maggiolino, A.; Centoducati, P.; Tateo, A. Colour Changes in Meat of Foals as Affected by Slaughtering Age and Post-thawing Time. Asian-Australas. J. Anim. Sci. 2012, 25, 1775-1779. [CrossRef] [PubMed]

86. Salueña, B.H.; Gamasa, C.S.; Rubial, J.M.D.; Odriozola, C.A. CIELAB color paths during meat shelf life. Meat Sci. 2019, 157, 107889. [CrossRef] [PubMed]

87. Hughes, J.; Oiseth, S.; Purslow, P.; Warner, R. A structural approach to understanding the interactions between colour, waterholding capacity and tenderness. Meat Sci. 2014, 98, 520-532. [CrossRef] [PubMed]

88. Mancini, R.A.; Hunt, M.C. Current research in meat color. Meat Sci. 2005, 71, 100-121. [CrossRef]

89. Warner, R.D. The eating quality of meat- IV Water-Holding Capacity and juiciness. In Lawrie's Meat Science; Toldrá, F., Ed.; Woodhead Publishing: Cambridge, UK, 2017; pp. 419-459.

90. Pearce, K.L.; Rosenvold, K.; Andersen, H.J.; Hopkins, D.L. Water distribution and mobility in meat during the conversion of muscle to meat and ageing and the impacts on fresh meat quality attributes-A review. Meat Sci. 2011, 89, 111-124. [CrossRef]

91. Oillic, S.; Lemoine, E.; Gros, J.-B.; Kondjoyan, A. Kinetic analysis of cooking losses from beef and other animal muscles heated in a water bath-Effect of sample dimensions and prior freezing and ageing. Meat Sci. 2011, 88, 338-346. [CrossRef]

92. Shanks, B.C.; Wulf, D.M.; Maddok, R.J. Technical note: The effect of freezing on Warner-Bratzler shear force val-ues of beef longissimus steaks across several post-mortem ageing periods. J. Anim. Sci. 2002, 80, 2122-2125.

93. Shackelford, S.; Morgan, J.; Cross, H.; Savell, J. Identification of threshold levels for Warner-Bratzler shear force in beef top loin steaks. J. Muscle Foods 1991, 2, 289-296. [CrossRef] 